\title{
Effects of Soil and Water Conservation on Selected Soil Physicochemical Properties and Its Implication on Soil Productivity in Ethiopia. A Review
}

\author{
Leta Hailu \\ Jimma Agricultural Research Center, PO box 192, Jimma, Ethiopia
}

\begin{abstract}
Soil erosion and land degradation have been a severe problem in the Ethiopian highlands due to dense population, high livestock density and intensive crop production in the area. Soil and water conservation practice is one the mechanism used to reduce soil and associated nutrient loss; thus, reduce the risk of production. Efforts were started through soil and water conservation strategy at a large scale on farmland since the mid-1970 and 1980's. However, its effectiveness depends on specific site conditions. Therefore, reviewing the effects and implication of the soil and water conservation practices on selected soil physicochemical properties and soil productivity is essential. The study conducted in various part of the country showed that the implemented soil bund reduced annual runoff and soil loss at different rates. Soil and water conservation have improved the soil physicochemical properties on conserved cropland (BD, SMC, infiltration rate, clay content, $\mathrm{pH}, \mathrm{CEC}$, av. $\mathrm{K}$, av. $\mathrm{P}, \mathrm{SOC}$ and $\mathrm{TN}$ ) than in the adjacent cropland without soil and water conservation measures. In contrast, the constructed soil and water conservation has shown no significant variations as compared to adjacent cropland in a study conducted at Dawuro zone, Southern Ethiopia. Soil and water conservation, reduce the removal of fertile topsoil and improves soil moisture, which favors crop growth as a result grain yield of the crops were increased at various rates based on agro ecology, crop type and local management practices. In general, the effect of constructed soil and water conservation had clearly showed positive impact on selected soil physicochemical properties and crop yields. Therefore, maintenance of the existing soil and water conservation structures is highly recommended to sustain its benefit, productivity and production; hence, improve the livelihood of the community.
\end{abstract}

Keywords: land degradation, soil and water conservation, soil properties, soil productivity.

DOI: $10.7176 / \mathrm{JEES} / 9-5-02$

Publication date:May $31^{\text {st }} 2019$

\section{Introduction}

Agriculture contributes substantial role in the Ethiopian economy (MoFED 2010). It creates employment opportunity for about 83-85 percent for the community and contributes 43-50 percent for growth and domestic products (GDP) and 90 percent of the total foreign exchange earnings. It also provides about 70 percent of the raw materials for different industries in the country to realize the agricultural-development-led industrialization strategy. Furthermore, the role of gender in agricultural system is critical, women contributes as much as 70 percent of on-farm labor (Awulachew et al. 2006, MoARD 2010).

The majority of the population of the country is inhabited in a rural highland area where heavily depends on subsistence farming with no or low management of farmland that exacerbate soil erosion and land degradation. Small holder farmers are predominantly responsible for producing about 90 percent of the agricultural production (Awulachew et al. 2006 Gebreyesus \& Kirubel 2009; MoARD 2010; Birhanu 2014). Nevertheless, much of the land is degraded in sub-Saharan Africa, particularly in Ethiopia, where poor farmers highly depend on land for their livelihood improvements (Nkonya et al. 2008).

Soil erosion and land degradation have been increasing in Ethiopian highlands due to the existence of arable land $(90 \%)$, high human population $(90 \%)$ and livestock density $(60 \%)$ which resulted in natural resources degradation (Hurni et al. 2010; Darley 2015). This is a noticeable environmental concern that results in declining agricultural productivity, food insecurity and rural poverty (MoARD 2010; Gashaw et al. 2014; Kirui 2016). Moreover, the loss of soil has dramatically reduces land productivity and biodiversity; and also disturbs downstream water quality through sedimentation and eutrophication. Thus, it affects ecosystem health and service that many people depend on for their livelihood (Darley 2015).

Soil erosion is predominant on arable land, in which the average annual soil loss is estimated to be 12 $\mathrm{t} / \mathrm{ha} /$ year. It ranges up to $300 \mathrm{t} / \mathrm{ha} / \mathrm{year}$ on steep slope fields and low vegetative cover area (Demeke 2003). This loss of soil from arable land is associated with the loss of nutrients and soil moisture that affects food production and worsens poverty. That contributes to the inability of investing in natural resource conservation and hinders sustainable development of the agricultural sector (Kirui 2016). Consequently, adoption of soil and water conservation is necessary to limit the soil loss to a tolerable level (11 tons ha $\left.{ }^{-1} \mathrm{yr}^{-1}\right)$ (Morgan 2005; Tulu 2011).

Soil and water conservation practice is a mechanism of reducing the soil loss and risk of production that has 
been adopted by the farmers (Kato et al. 2011). Its practice was dated back to mid-1970s and 1980s at large scale on farmland (Aklilu 2006). Accordingly, the adopted soil and water conservation was capable of improving soil physicochemical properties and enhances soil productive capacity (Bekele et al. 2016; Adimassu et al. 2017; Fisseha \& Alemayehu 2018). The effectiveness of soil and water conservation is depends on specific site conditions, which is depending on soil depth, topography and local climate of the area (Kato et al. 2011). Therefore, soil and water conservation interventions were undertaken in different parts of the country and reviewing its effects on selected soil physicochemical properties and its implication on soil productivity is essential.

\section{Over View of Soil Erosion and Land Degradation in Ethiopia}

Soil erosion is a destructive process altering and changing the topsoil layer and soil carbon stocks through selective removal of fertile top soil along the slope (Olson et al. 2016). In Ethiopia, soil erosion is one of a serious problem challenging the agricultural sector and economic development (Hurni et al. 2016). It is severe in general and particularly in the highland areas where land highly degraded and exacerbates the prevailing of food insecurity in the country (Belayneh et al. 2017).

The various studies conducted in the country point out that the loss of soil due soil erosion is at large rate. For instance the study conducted in May Zegzeg catchment in Tigray highlands showed that the average rate of soil loss was about $14 \cdot 8 \mathrm{t} \mathrm{ha}^{-1} \mathrm{yr}^{-1}$ (Nyssen et al. 2008). Likewise, in Koga River the average annual soil loss rate was $30.2 \mathrm{t} \mathrm{ha}^{-1} \mathrm{yr}^{-1}$ which ranges from $12.1 \mathrm{t} \mathrm{ha}^{-1} \mathrm{yr}^{-1}$ to $456.2 \mathrm{t} \mathrm{ha}^{-1} \mathrm{yr}^{-1}$ for the outlet and the steep slope area of the watershed, respectively (Molla \& Sisheber 2017). Similarly, in the north western highlands of Ethiopia, in the Geleda watershed of the Blue Nile basin, the soil loss in the steep areas of the watershed extends up to $237 \mathrm{t} \mathrm{ha}^{-1}$ year $^{-1}$ (Gashaw et al. 2017). This indicates that erosion rates exceeds tolerable levels and affects the productive capacity of the soil system (Guerra et al. 2017). Besides, the loss of soil also results in loss of water, nutrients, soil organic matter, and soil biota (Pimentel \& Burgess 2013). These all indicate soil erosion exceed the generation of new topsoil which leads to decline in soil productivity, low agricultural yield; that need adoption of integrated soil and water conservation to reverse the problem. Thus, soil erosion control is being important under every type of land use (Morgan 2005; Kumar \& Pani 2013).

\section{Soil and Water Conservation and Its Adoption in Ethiopia}

Soil and water conservation is a key method in reversing land degradation in the country. To reduce soil erosion and land degradation, various soil and water conservation measures have been adopted throughout the country (Wolka et al. 2009). The indigenous agricultural system in Konso zone is characterized by stone-based terraces and well integrated Agroforestry practices. It has existed for at least four hundred years. The strength of the system is expressing culture and its institutions that contribute to this kind of agriculture (Beshah 2003)

The survey result reveals that there are various indigenous and adopted soil conservation practices in Darimu and Chewaka Woredas of Illu Ababora Zone. Among these, fallowing, manure, contour plowing, crop rotation and waterways are indigenous soil conservation practices and terracing, soil bund, fayna juu, grass strip, chomo grass and elephant grass are some of the adopted soil conservation practices in the area (Belayneh et al. 2017).

In Ethiopia, adoption of large scale soil and water conservation techniques on farm lands was dated back in the early 1970's (Wolka et al. 2009). For instance soil bunds were introduced in Wolaita zone to conserve both soil and water in an experimental catchment in the early 1980s, which have shown moisture and nutrient conservation effects (Beshah 2003). Introduction of soil and water conservation technology strongly reduces runoff production and soil loss. Stone bunds building lead to soil loss reduction of 58 to $66 \%$ in rangeland while the reduction rate ranges from 43 to $50 \%$ in cropland at May Leiba catchment in central Tigray, northern Ethiopia (Taye et al. 2013).

Indigenous soil conservation techniques alone became less efficient when compared to modern technologies of conservation measures. Modern methods of soil and water conservation were unsustainable due to unpopular top-down policies and lack of community participation that leads past efforts of the modern intervention programs to being ineffective. Hence, to cope up with the problems, indigenous techniques of soil and water conservation needs improvement and the modern ones also needs adaptation to the environment and involving the community at all levels is vital (Osman et al. 2000).

\section{Effectiveness of Soil and Water Conservation}

Soil and water conservation measures interventions take various forms throughout the country to reduce soil erosion and land degradation problem based on agro-ecology of the area (Ademe et al. 2016). According to Nyssen et al. (2007), the constructed stone bund was trapped $76 \%$ of the total soil loss in the study conducted in northern Ethiopia. Similarly, the study conducted in Jawe-gumbura watershed had reported a $28 \%$ annual runoff and $47 \%$ soil loss reduction. These are therefore used as evidence for effectiveness of soil bund in reducing of 
runoff and soil losses. Consequently, soil bund has reduced losses of soil nutrients and organic carbon associated with conserved soil. On the other hand, construction of soil bunds takes out cultivable area out of production by 8.6 percent as compared to control, which is needed to compensate by integrating with biological conservation and increasing yield obtained from conserved land (Adimassu et al. 2017).

The farmers have several criteria to select soil and water conservation practices. The economic benefit is the one given top priority to choose the structure. Therefore, strengthening participatory planning with farmers and developing best future alternatives that provide with immediate benefit along with the long term benefit obtained from soil and water conservation investment is required (Adimassu et al. 2013).

\subsection{Soil and Water Conservation Impacts on Selected Soil Physicochemical Properties}

Soil and water conservation practice improves the soil properties through reducing runoff velocity, because in the absence of soil and water conservation, the soil is washed-out down the slope by erosion. Along with the loss of soil, it results in loss of water, nutrients, soil organic matter and soil biota. This severely harms the proper functioning of the soil system (Pimentel \& Burgess 2013). Soil erosion lowers base saturation and soil organic carbon (SOC) contents; as a result, it decreases the soil $\mathrm{pH}$. The $\mathrm{pH}$ of the soil influences the availability of phosphorus, which is low for non-conserved agricultural land (Amare et al. 2013; Bekele et al. 2016).

The study conducted in different parts of the country points out that cropland with soil and water conservation practice showed significant variation in soil physicochemical properties (Bekele et al. 2016; Ademe et al. 2017; Fisseha \& Alemayehu 2018). Similarly, Ademe et al. (2016), indicates that soil and water conservation improves the soil properties on conserved cropland $\left(\mathrm{pH}, \mathrm{K}^{+}\right.$, available $\mathrm{P}, \mathrm{SOC}, \mathrm{TN}, \mathrm{CEC}$ and clay content) than in the adjacent crop land that is without soil and water conservation measures. This indicates the positive impacts of soil and water conservation practices in improving the nutrient status of the cropland. In contrast to this, Wolka et al. (2011) reported that the constructed soil bund had not affected most of the tested soil properties in cropland with soil and water conservation as compared to the non-conserved one. This might be due to past erosion and land use practice of the site.

Table 1. Summary of soil and water conservation effects on selected soil physicochemical properties

\begin{tabular}{|c|c|c|c|c|c|c|c|c|c|c|c|c|}
\hline \multirow{3}{*}{  } & \multirow{3}{*}{ 竎 } & \multirow[b]{3}{*}{ 竧 } & \multirow{3}{*}{ 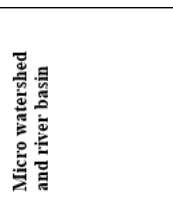 } & \multicolumn{6}{|c|}{ Agro-climatology } & \multirow[b]{3}{*}{$\frac{.}{\stackrel{2}{E}}$} & \multirow{3}{*}{ 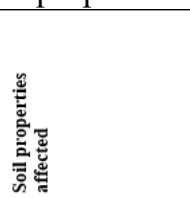 } & \multirow[b]{3}{*}{ 㐁 } \\
\hline & & & & \multicolumn{2}{|c|}{ Rain fall (mm) } & \multicolumn{2}{|c|}{$\begin{array}{l}\text { Temp. } \\
\text { (C9) }\end{array}$} & \multicolumn{2}{|c|}{ Altitude (m) } & & & \\
\hline & & & & 竞 & 㟧 & 妾 & 嵌 & 竞 & 尝 & & & \\
\hline $\begin{array}{l}\text { Stone bund } \\
\text { (graded) }\end{array}$ & $\begin{array}{l}\text { West Showa } \\
\text { Zone, ORS }\end{array}$ & 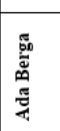 & $\begin{array}{l}\text { Harowerke, } \\
\text { Bilu Nile river } \\
\text { system }\end{array}$ & & ఫ్తి & $\approx$ & 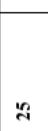 & ले & $\underset{\substack{\infty \\
\text { a }}}{ }$ & $\begin{array}{l}\text { Nitosols, } \\
\text { Vertisols and } \\
\text { Lithosols }\end{array}$ & $\begin{array}{l}\text { SMC, BD, SOM, TN } \\
\text { and CEC }\end{array}$ & \begin{tabular}{|l|} 
Challa et al \\
2016
\end{tabular} \\
\hline Soil bund & $\begin{array}{l}\text { West Showa } \\
\text { Zone, ORS }\end{array}$ & 竟 & $\begin{array}{l}\text { Galessa, Centeral } \\
\text { high land \& Awasa } \\
\text { basin }\end{array}$ & & 宇 & 0 & iి & స్ఞి & ঃ్లి & Halpic luvisols & $\mathrm{N}, \mathrm{P}, \mathrm{K}$ and $\mathrm{SOC}$ & \begin{tabular}{|l} 
Adimmasu et \\
al. 2014
\end{tabular} \\
\hline Soil bund & $\begin{array}{l}\text { Western } \\
\text { Ethiopia, } \\
\text { ORS }\end{array}$ & 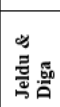 & Bilu nile basin & ఓू & छ్స్ & $\equiv$ & ส & 究 & 胥 & & SMC & \begin{tabular}{|l} 
Erkossa et \\
al.2018
\end{tabular} \\
\hline Soil bund & Awi zone, ARS & 尊 & & $\stackrel{\circ}{్}$ & 总 & $\approx$ & 28 & ส్สి & :్రి & & $\begin{array}{l}\text { SOC, TN, BD, } \\
\text { infiltration rate, } \\
\text { bund height }\end{array}$ & $\begin{array}{l}\text { Gebreselassie } \\
\text { et al. 2009 }\end{array}$ \\
\hline Soil bund & $\begin{array}{l}\text { South Gonder } \\
\text { Zone, } \\
\text { ARS }\end{array}$ & 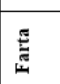 & $\begin{array}{l}\text { Upper Bilu Nile } \\
\text { basin }\end{array}$ & & $\stackrel{\infty}{2}$ & & & $\frac{8}{4}$ & క్ & $\begin{array}{l}\text { Cambisols, } \\
\text { Regosols and } \\
\text { Leptosols }\end{array}$ & $\begin{array}{l}\text { SOC, TN, Av.P, BD, } \\
\text { infiltration rate and } \\
\text { soil texture }\end{array}$ & $\begin{array}{l}\text { Demelash \& } \\
\text { Stahr } 2010\end{array}$ \\
\hline $\begin{array}{l}\text { Soil bund (level } \\
\text { and graded) }\end{array}$ & $\begin{array}{l}\text { Dawuro zone, } \\
\text { SNNPRS }\end{array}$ & 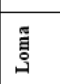 & $\begin{array}{l}\text { Bokole. drains to } \\
\text { Omo River. }\end{array}$ & 亭 & : & $\vec{n}$ & $\stackrel{n}{4}$ & $\stackrel{\circ}{=}$ & 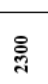 & Orthic Acrisols & $\begin{array}{l}\text { SOC, Av-P, Av.K, } \\
\text { and pH higher in } \\
\text { control }\end{array}$ & $\begin{array}{l}\begin{array}{l}\text { Wolka et } \\
\text { al.2011 }\end{array} \\
\end{array}$ \\
\hline Soil bund & $\begin{array}{l}\text { Gedeo } \\
\text { Zone, SNNPRS }\end{array}$ & 总 & & ప్త్ & 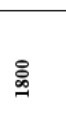 & $\approx$ & 28 & & & & $\begin{array}{l}\mathrm{pH}, \mathrm{K}^{+}, \mathrm{P}, \mathrm{TN}, \\
\text { SOC, \%clay and } \\
\text { CEC }\end{array}$ & $\begin{array}{l}\text { Ademe } e t \\
\text { al.2017 }\end{array}$ \\
\hline
\end{tabular}

Av. $-P=$ Available phosphorus; Av.K=Available potassium; ARS=Amahara regional state; $B D=B u l k$ density; $C E C=$ Cation exchange capacity; K=Potassium; $N=$ Nitrogen; ORS=Oromia regional state; $P=$ phosphorus; $p H=$ hydrogen ion concentration; SMC=Soil moisture content; SOC=Soil organic carbon; SNNPRS=Southern nations, nationalities' peoples regional state; TN=Total nitrogen.

\subsection{Effect of Soil and Water Conservation on Soil Productivity and Crop Yield}

In Ethiopia, a range of policies, strategies and institutional arrangements has been adopted to improve agricultural production; however, the sector still suffers with the detrimental effects of soil degradation which undermines potential soil productivity and requires enormous costs for reversing the degradation (Amsalu 2015). Soil erosion an impact on soil productivity; most likely caused by deterioration in soil physical properties. In an eroded landscape the physical and chemical properties of the soils are changed (Arriage \& Lowery 2003). Soil 
degradation affects water availability, nutrient reserves and crop growth; thus, it leads to yield loss (Kumar \& Pani 2013).

Inappropriate soil management intensifies the effect of erosion on soil productivity; thus, considering appropriate soil management for effective erosion control and maintaining soil productivity is crucial (Den Biggelaar et al. 2004). Soil and water conservation reduces the removal of fertile topsoil and improves soil moisture that favors crop growth; hence, increase crop residue input, which builds up soil organic carbon stock and plant nutrients on conserved cropland. Soil organic matter improves soil aggregate, which influence total porosity of the soil that negatively affects soil bulk density (Amare et al. 2013; Bekele et al. 2016; Oldfield et al. 2018). Low bulk density indicates a favourable condition for a better root growth, improved aeration, and increased infiltration, which improves the productive capacity of the agricultural land (Gupta 2010).

Soil bunds of different ages were able to improve soil properties that affect crop yield on conserved farmland, in northern Ethiopia. The croplands with soil bund had improved the crop yield from 0.584 to $0.65 \mathrm{t}$ ha ${ }^{-1}$ which compensates the financial cost expends for building bunds (Nyssen et al. 2007). Likewise, the soil bund constructed at Absela site of Awi administrative Zone located in the Blue Nile Basin had improved yield of the crop as compared to non-conserved adjacent cropland. The average yield obtained from accumulation zone had increased crop grain yield by $29.8 \%$ as compared to loss zone; this might be due to accumulation of soil organic matter and fertile topsoil above the bunds in the deposition zone of the bund (Gebreselassie et al. 2009).

Furthermore, the use of soil bund had increased soil moisture content under plot with contour bund. On average $24.6 \%$ of yield increment was reported. This point out the contribution of the soil and water conservation in conserving the soil productivity that enhances crop yield under the conserved plot of cropland than non-conserved adjacent plot of cropland (Erkossa et al. 2018). Therefore, this implies that soil bund reduce runoff velocity and hence soil erosion. Accordingly, the practice maintains the productive capacity of the soil. To sustain the above mentioned effects of the practice, it requires regular maintenance and awareness creation to fully engaging the farmers in the practice from planning to execute of the conservation measures according to specific agro ecology of the site.

\section{Conclusion}

This paper attempts to review the effect of soil and water conservation on soil physicochemical properties in focus to its implication on soil productivity in Ethiopia. Even though, the agricultural sector substantially contributes to the economy, it is threatened by soil erosion and affected by the loss of the soil productivity. As described above, soil erosion and land degradation affect the soil productive capacity and proper functioning of the soil by deteriorating physical, chemical and biological properties of the soil which leads to yield losses. However, most of the studies identified and compared in this review suggested that the implementation of structural soil and water conservation reduced runoff and soil losses. This reduces the loss of associated nutrients and soil organic carbon that improves the soil physicochemical properties and productive capacity of the agricultural land. Thus, enhances the soil productive capacity and crop yield in conserved cropland than croplands without soil and water conservation. To sum-up, structural soil and water conservation intervention had profound effect on soil physicochemical property improvement in different part of the country that able to improve soil productive capacity and crop yield.

\section{References}

Ademe, Y., Kebede, T., Mullatu, A. \& Shafi, T., (2017). Evaluation of the effectiveness of soil and water conservation practices on improving selected soil properties in Wonago district, Southern Ethiopia. Journal of Soil Science and Environmental Management, 8, 70-79.

Adimassu, Z., Gorfu, B., Nigussie, D., Mowo, J., \& Hilemichael, K., (2013). Farmers' preference for soil and water conservation practices in central highl\&s of Ethiopia. African Crop Science Journal, 21, 781-790.

Adimassu, Z., Mekonnen, K., Yirga, C. \& Kessler, A., (2014). Effect of soil bunds on runoff, soil \& nutrient losses, \& crop yield in the central highlands of Ethiopia. Land Degradation and Development, 25, 554-564.

Adimassu, Z., Tamene, L., Schmitter, P., Yaekob, T., \& Barron J., (2017). The effect of soil bunds on run-off, soil loss, soil moisture dynamics and crop yield in the Jawe-gumbura watershed, Ethiopia. Published by International Livestock Research Institute. [On line] Available: http://www.africa-rising.net.

Aklilu, A., (2006). Caring for the land: Best practices in soil and water conservation in Beressa watershed, highlands of Ethiopia. Thesis Wageningen UR.

Alemayehu, T. \& Fisseha, G., (2018). Effects of soil and water conservation practices on selected soil physicochemical properties in Debre-Yakob Micro-Watershed, Northwest Ethiopia. Ethiopian Journal of Science and Technology, 11, 29-38.

Amsalu A., (2015). Institutional Context for Soil Resources Management in Ethiopia: a Review report, unpublished, Addis Ababa. (September, 2015), 17p.

Arriaga, F. J., \& Lowery, B., (2003). Soil physical properties and crop productivity of an eroded soil amended 
with cattle manure. Soil science, 168, 888-899.

Awulachew, S.B.; Menker, M.; Abesha, D.; Atnafe, T.; Wondimkun, Y. (Eds.)., (2006). Best practices and technologies for small scale agricultural water management in Ethiopia. Proceeding of a MoARD/MoWR/USAID/IWMI symposium and exhibition held at Ghion Hotel, Addis Ababa, Ethiopia (79 March, 2006). Colombo, Sri Lanka: International Water Management Institute, 190.

Bekele, M., Lemenih, M., \& Regassa, A., (2016). The Effects of Integrated Soil Conservation Practices on Soil Physico-Chemical Properties: The Case of Menesibu District, West Ethiopia. Journal of Natural Sciences Research, 23, 35

Belayneh M., Abera A., Tadesse G., (2017). Soil Degradation and Conservation Practices: the case of Darimu and Chewaka woredas, Illu Ababora Zone, Ethiopia. International Journal of Scientific and Research Publications, 7, 562-568.

Beshah T., (2003). Understanding Farmers Explaining Soil and Water Conservation in Konso, Wolaita and Wello, Ethiopia, Tropical Resource Management Paper, No. 41.

Birhanu, A., (2014). 'Environmental degradation and management in Ethiopian Highlands: review of lessons learned', International Journal of Environmental Protection and Policy, 2, 24-34.

Daley, B., (2015). Environmental Issues in Ethiopia and Links to the Ethiopian Economy. [On line] Available at http://dx.doi.org/10.12774/eod hd.september2015.daleyb.

Demeke, A.B. (2003). Factors influencing the adoption of soil conservation practices in North-western Ethiopia. Discussion Papers (Germany).

Den Biggelaar, C., Lal, R., Wiebe, K. \& Breneman, V., (2004). The global impact of soil erosion on productivity. I. Absolute and relative erosion-induced yield losses. Advances in Agronomy, 81, 1-48.

Erkossa, T., Williams, T.O. \& Laekemariam, F., (2018). Integrated soil, water and agronomic management effects on crop productivity and selected soil properties in Western Ethiopia. International Soil and Water Conservation Research. [On line] Available: https://doi.org/10.1016/j.iswcr.2018.06.001.

Gashaw, T., Bantider, A. \& Silassie, H. G., 2014. Land degradation in Ethiopia: causes, impacts and rehabilitation techniques, Journal of Environmental and Earth Science, 4, 98-104.

Gashaw, T., Tulu, T. \& Argaw, M., (2017). Erosion risk assessment for prioritization of conservation measures in Geleda watershed, Blue Nile basin, Ethiopia. Environmental Systems Research, 6, 1.

Gebreselassie, Y., Amdemariam, T., Haile, M., \& Yamoah, C., (2009). Lessons from upstream soil conservation measures to mitigate soil erosion and its impact on upstream and downstream users of the Nile River. Improved Water and Land Management in the Ethiopian Highlands: Its Impact on Downstream Stakeholders Dependent on the Blue Nile, CP 19 Project workshop Proceedings, 171-183.

Gebreyesus, B. \& Kirubel, M., (2009). Estimating soil loss using universal soil loss equation (USLE) for soil conservation planning at Medego Watershed, Northern Ethiopia, Journal of American Science, 5, 58-69.

Guerra, A. J. T., Fullen, M. A., Jorge, M. C. O., Bezerra, J. F. R., Shokr, M. S., (2017). Slope processes, mass movement and soil erosion: A review. Pedosphere, 27, 27-41.

Hurni, H., Solomon Abate, Amare Bantider, Berhanu Debele, Ludi E, Portner B, Birru Yitaferu, Gete Zeleke., (2010). Land degradation and sustainable land management in the Highlands of Ethiopia. In: Hurni H, Wiesmann U, editors; with an international group of coeditors. Global Change and Sustainable Development: A Synthesis of Regional Experiences from Research Partnerships. Perspectives of the Swiss National Centre of Competence in Research (NCCR) North South, University of Bern, Vol. 5. Bern, Switzerland: Geographica Bernensia.

Kato, E., Ringler, C., Yesuf, M. \& Bryan, E., (2011). Soil and water conservation technologies: a buffer against production risk in the face of climate change? Insights from the Nile basin in Ethiopia. Agricultural Economics, 42, 593-604.

Kirui, O.K., (2016). Impact of land degradation on household poverty: evidence from a panel data simultaneous equation model. In Invited paper presented at the $5^{\text {th }}$ International Conference of the African Association of Agricultural Economists, Addis Ababa, Ethiopia. (September,2016), 23-26.

Kumar, H. \& Pani, P., (2013). Effects of soil erosion on agricultural productivity in semi-arid regions: the case of Lower Chambal Valley. Journal of Rural Development, 32,165-184.

MoFED (Ministry of Finance and Economic Development), (2010). The Federal Democratic Republic of Ethiopia Growth and Transformation Plan (GTP) 2010/11-2014/15 Draft, Addis Ababa, (September, 2010)

MoARD (Ministry of Agriculture and Rural Development), (2010). Ethiopia's Agricultural Sector Policy and Investment Framework (PIF) 2010-2020, Draft Final Report, 1-15.

Molla, T., \& Sisheber, B., (2017). Estimating soil erosion risk and evaluating erosion control measures for soil conservation planning at Koga watershed in the highlands of Ethiopia. Solid Earth, 8, 13.

Morgan, R. P. C., (2005). Soil Erosion and Conservation. Third edition, National Soil Resources Institute, Cranfield University, Blackwell publishing, Oxford, 1-24.

Nkonya, E., Pender, J., Kaizzi, K.C., Kato, E., Mugarura, S., Ssali, H. \& Muwonge, J., (2008). Linkages between 
land management, land degradation, and poverty in Sub-Saharan Africa: The case of Uganda (Vol. 159). Intl Food Policy Res Inst.

Nyssen, J., Poesen, J., Gebremichael, D., Vancampenhout, K., D’aes, M., Yihdego, G Govers, G., Leirs, H., Moeyersons g, J., Naudts J., Haile, M., Deckers, J., \& Haregeweyn, N., (2007). Interdisciplinary on-site evaluation of stone bunds to control soil erosion on cropland in Northern Ethiopia. Soil and Tillage Research, 94, 151-163.

Nyssen, J., Poesen, J., Moeyersons, J., Haile M., \& Deckers J., (2007). Dynamics of soil erosion rates and controlling factors in the Northern Ethiopian Highlands - towards a sediment budget, Earth Surface Processes and Landforms, Published online in Wiley Inter Science.156.

Oldfield, E.E., Wood, S.A. \& Bradford, M.A., (2018). Direct effects of soil organic matter on productivity mirror those observed with organic amendments. Plant and Soil, 423, 363-373.

Olson, K.R., Al-Kaisi, M., Lal, R. \& Cihacek, L., (2016). Impact of soil erosion on soil organic carbon stocks. Journal of Soil and Water Conservation, 71, 61A-67A.

Osman M., Skowronek A. \& Sauerborn P., (2000). Land and Water Resources Management in Ethiopia: What did we learn, where do we go? Deutscher Tropentag, Hohenheim .

Taye G., Poesen, J., Van Wesemael, B., Vanmaercke, M., Daniel T., Deckers, J., Goosse, T., Maetens, W., Nyssen, J., Hallet, V., Nigussie H., (2013). Effects of land use, slope gradient, and soil and water conservation structures on runoff and soil loss in semi-arid northern Ethiopia. Physical Geography, 34, 236259.

Tulu, T., (2011). Soil and water conservation for sustainable agriculture, Mega publishing and distribution P.L.C, Addis Ababa. 